\title{
CRIME AND PUNISHMENT: ADAM SMITH'S THEORY OF SENTIMENTAL LAW AND
}

\section{ECONOMICS}

BY

\author{
MARIA PIA PAGANELLI*
}

FABRIZIO SIMON**

\begin{abstract}
For Adam Smith a crime is not the result of a rational calculation of loss and gain, but the consequence of envy and a vain desire to parade wealth to attract the approbation of others, combined with a natural systematic bias in overestimating the probability of success. Similarly, Smith does not conceive of legal sanctions as a rational deterrent, but as deriving from the feeling of resentment. While the prevailing approach of the eighteenth century is a rational explanation of crime and a utilitarian use of punishment, Adam Smith instead builds his theory of criminal behavior and legal prosecution consistently on the sentiments. A well-functioning legal system is thus an unintended consequence of our desire to bring justice to the individual person, not the result of a rational calculation to promote the public good, just like a well-functioning economic system is the unintended consequence of our desire to better our own condition, not the result of a rational calculation to promote public good.

* Trinity University - Economics. Contact: mpaganel@,trinity.edu

** University of Palermo. Contact: fabrizio.simon@unipa.it

This "preprint" is the peer-reviewed and accepted typescript of an article that is forthcoming in revised form, after minor editorial changes, in the Journal of the History of Economic Thought (ISSN: 1053-8372), issue TBA. Copyright to the journal's articles is held by the History of Economics Society (HES), whose exclusive licensee and publisher for the journal is Cambridge University Press. (https://www.cambridge.org/core/journals/journal-of-thehistory-of-economic-thought) This preprint may be used only for private research and study and is not to be distributed further.
\end{abstract}

The preprint may be cited as follows:

Paganelli, Maria Pia and Simon, Fabrizio. Crime and Punishment: Adam Smith's Theory Of Sentimental Law and Economics. Journal of the History of Economic Thought (forthcoming). Preprint at SocArXiv, osf.io/preprints/socarxiv 


\section{Crime and Punishment: Adam Smith's Theory of Sentimental Law and Economics}

Why do we commit crimes? How can we punish crime effectively? The two questions are interrelated. To punish crime one needs to understand why there is crime to begin with. The interrelation of these two questions, and their historical context, is relevant to better understand human beings, and to reform a criminal justice system that is deemed outdated.

In $18^{\text {th }}$ century Europe, the challenges to understanding crime and punishment come from both intellectual curiosity and a reforming spirit. The "Science of Man" that David Hume introduces calls for a scientific understanding of human nature and human conduct in all their aspects, including deviant behaviors. And the criminal justice system often symbolizes the outdated, violent, and above all irrational Ancien Regime's institutions (Foucault 1975). Legal Enlightenment is a term of art that is commonly used to indicate the intellectual movement that deals mostly with how to rationally reform existing legal systems (see for example Marcos 2009, Grossi 2010, and Padoa Schippa 2017). Its defining characteristics are: the lay definition of crime as social damage which produces a loss of welfare; the idea of punishment whose only purpose is the defense of society against crimes; and the attempt to elaborate a rational theory of punishment to discourage the greatest number of crimes with the minimum social costs.

What distinguishes the authors of this new trend, such as Montesquieu ([1748] 1989), Cesare Beccaria ([1764] 1986), Pietro Verri ([1776-77] 2010), Voltaire ([1777] 1999), Gaetano Filangieri ([1780-91] 1984), and Jeremy Bentham ([1780] 1948] is the utilitarian explanation of criminal behavior. For them, crime is the choice of a rational individual who calculates expected value and costs and who rationally choses to commit a crime when the expected value of the crime exceeds the expected cost of its legal consequences. Reform of the criminal system implies tinkering with these expected costs and benefits so that the expected costs would exceed the 
expected benefits, thus creating deterrence and an eventual decrease in crime. Gary Becker and Richard Posner (e.g. Becker 1968; Posner 1973) place the contemporary branch of economics known as Law and Economics within the tradition of this Legal Enlightenment literature.

Even in the narrower Scottish context, and of the University of Glasgow in particular, where Smith taught Jurisprudence, the dominant justification for the existence of criminal punishment was the utilitarian explanation of deterrence. As John Cairns (1988) testifies, the standard teaching of Scottish Law implied that crimes are a threat against society, and need to be punished for the public interest and for the terror of others as Erskine ([1754] 2018) would say (see also Forbes ([1730] 2013), Mackenzie ([1722] 2010), Bayne ([1730] 2010). Even Henry Home, Lord Kames ([1758] 2019), who has a sentiment-based theory of punishment based on resentment and indignation, but as we will see differs from Smith in having no impartial spectator to control revenge, sees punishment as a deterrent tool for public control for public utility. David Hume himself ([1739] 1976) also offers a theory of justice as an "artificial virtue" based on utility (Raphael 1972-3, Fleischacker 1988).

In this intellectual context, Adam Smith stands out as different. Smith not only is well familiar with the views of his predecessors and contemporaries in Scotland, but he also knows the works of Beccaria and Verri and other Legal Enlightenment scholars- in his library there are copies of their works (Mizuta 2000). Yet he distances himself from the Scottish and European mainstream of his age, grounding his theory of crime and punishment consistently in human sentiments rather than rationalism and utilitarianism. Smith proposes a theory of crime and punishment which is far from, if not even opposite to, Cesare Beccaria, Gaetano Filangieri, and later Jeremy Bentham (Simon 2009). Smith was joined in this by his student and successor in teaching jurisprudence at Glasgow, John Millar ([1779] 2006), who followed a closely similar approach where a wrong is a wrong to the individual and, even if the public interest is also wronged, its role is secondary (Cairns 1988). 
We suggest that this deep divergence is the consequence of a different anthropological view of human beings. For Smith, people are not hedonistic pleasure seekers nor rational calculators (see among others Witztum and Young 2013). In The Theory of Moral Sentiments (A. Smith [1759] 1984), indeed, Smith describes persons whose strongest wish is not the egoistic satisfaction of their needs but who, on the contrary, seek social interactions which bring the happiness of shared feelings of reciprocal esteem (e.g. TMS I.i.1.1, p. 9. TMS I.i.2.1, p. 13-14, among others). This view of human beings offers a consistent understanding of both the motivation to commit a crime and the justification of its punishment, even if it may take different forms in different historical contexts. As Craig Smith (2018) points out, this sentimental approach is typical of Adam Smith. Adam Smith grounds even philosophy in sentiments and the psychological need to understand the world. Utility is not an original motivation of scientific enquiry, just as it is not a motivation of crimes or punishments.

In this, we follow D.D. Raphael (1972-73)'s understanding of Smith as non-utilitarian (see among many also Witzum and Young 2013, cf. Hollander 2016). But while Raphael looks at Smith's general philosophy and contrasts it (mostly) with Hume's, we contextualize Smith's discourse on the criminal justice system within the Enlightenment debate on reforming the criminal justice. Thus, we add to the existing analysis of Smith such as Neil MacCormick (1981), Knud Haakonssen (1981), Alan Norrie (1989), Ralph Lindgreen (1994), Eric Miller (1996), John Salter (1999), Gloria Vivenza (2008), and Richard Stalley (2012), which tend to look only at the justification of punishment, but not at the motivation of crime, nor at the historical contextualization of the criminal justice system. We instead focus on Smith's understanding of both the sentimental motivation of crime and of punishment and his historical jurisprudence; we thus highlight how Smith focuses on the individual person and their passions as opposed to an explicit attempt to achieve social optimality, making his legal theory consistent with his economic theory of individual 
actions and unintended social consequences. Our analysis of Smith's view of human nature allows us to present a more complete picture of Smith's understanding of crime and institutional formation.

\section{Why crime?}

If Smith buys into the Humean "science of man" (Phillipson 2010), he also buys into the Humean idea of a philosopher as an "anatomist", someone who just describes how things are, rather than as a "painter" who shows how they should be (C. Smith 2018). Smith's primary concern is thus with the understanding of how we develop and use moral judgment, rather than with teaching people how to act, as his teacher Francis Hutcheson and his contemporary Adam Ferguson, for example, did (Campbell 2013). The recognition of Smith's description of a natural basis of justice (Haakonssen 1981) is unambiguous in the literature, even if some sees it is a fault in Smith's theory (Fleischacker 2005) so big that it may have prevented Smith from completing his third planned book on jurisprudence (Griswold 1999), while others see it instead as an application of what Frank Knight (1944) would later call a relative-absolute (Rizzo forthcoming). Smith does not seem interested in identifying universal principles of justice, instead he is interested in their formation and use, which may vary with their historical context, but which work as if absolute within each individual context.

Smith needs to find what is fixed and what is contingent in human behavior (A. Smith 1982, History of Metaphysics). He identifies a few characteristics that are constant in people across time and place - characteristics of human nature. What is relevant for us here is that we want to be, and we believe we are, the center of the universe and that all revolves around us (TMS III.iii.3-4, pp. 135-36): we want people's attention, we want their love and esteem. For Smith, we naturally want to be the (proper) object of the approbation of others, but we are also naturally biased by our selflove. 
The desire for approbation is one of those universal first principles from which Smith derives the explanation of complex social phenomenon and the possibility of formulating general laws. ${ }^{1}$ Smith clarifies that the desire to receive the approbation of others is related to, but not the same as, the desire to be the proper object of approbation. That is, we desire to be approvable, not just approved. The desire to be approved is derived from our innate desire to be approvable. We learn to become the proper object of approbation by observing and replicating approvable conduct in others, and by observing real or imaginary others looking at our own conduct. Becoming the proper object of approbation, as Smith describes it, is a lifelong process and never fully achieved (TMS III.3).

For Smith, our self-love makes us believe that things that are close to us are bigger than they are, and things that are farther away are smaller than they are. The loss of a little finger for us is more important that the loss of the distant population of China. The "eye of the mind" needs to learn with experience how to correctly perceive distances, which means that we need to realize we are not the center of the universe but just one in a multitude (Levy 1995; Paganelli 2017). This is achieved, in part at least, through the interaction of another innate sentiment: our desire to be lovely and not to be hateful, our desire to be approvable and not to be the proper object of disapprobation. Our desire to be lovely counterbalances our self-love and helps us lower the pitch of our passions so that we can gain the approbation of others, either a physical other or an imaginary other. This imaginary other, or what Smith calls the "inhabitant of our breast", or the "man within," is a spectator of our actions that learns to distance himself enough from us to become impartial in his judgment. He is a hypothetical individual, who is independent and unconnected with the facts and persons involved, whose opinion represents that of humanity in general and which could be shared by each man. He is an invisible advisor who helps us moderate our passions and develop moral

\footnotetext{
${ }^{1}$ On the influence of Newtonianism on Smith's works see Hetherington 1983; Cremaschi 1989;
} Redman 1993; Fiori 2012; Montes 2013. 
conduct (TMS III.iii.4, p. 137; TMS VII.ii.1.44, p. 292). The approbation of this spectator is the mechanism Smith adopts to give an objective value to an essentially subjective morality. So we cannot find a villain on earth willing to keep their little finger at the expense of the destruction of the entire population of China (TMS III.3.5, p. 136-137). The impartiality of this spectator, though, is never perfectly achieved, since we, as humans, are not perfectible.

One problem we encounter with the development of our impartial spectator is that we naturally admire the rich and thus we may conflate wealth with virtue. Indeed, for Smith we gain approbation in two ways: by being moral, and by parading our wealth. We naturally admire a just and virtuous man, just like we naturally look up to the rich and we look down on the poor. We want the rich in the spotlight and we do not want to see the poor. A poor person is ashamed of his poverty and wishes to become invisible to the eyes of others. A rich person proudly shows off his riches gaining everybody's attention and admiration. This is simply a description of human behavior. Smith does not endorse it or express moral judgment of it. But he remarks that this admiration for the rich exists, and is necessary, even if can be a source of moral corruption.

The admiration for the rich allows for peace and order in society. Peace and order in society rest in part on the authority of its leaders. Both wealth and virtue give authority, but since it is easier to recognize wealth than virtue, our natural admiration for the rich potentially decreases conflicts of legitimacy (TMS VI.i.1.21, p. 266. See also Tegos 2013).

Such admiration for the rich is also necessary because of the complexity and the contradictions of the human soul. Nature has predisposed it to balance another innate and spontaneous feeling: envy (WN V.i.b.2, pp. 709-10 and Smith's Lectures on Jurisprudence ([17623, 1766] 1982) LJB I.13, p. 402), which otherwise could destroy social coexistence and impede the accumulation of wealth and the consequent progress.

Riches glitter and are more easily recognizable than virtue. So we tend to rely more on wealth than on virtue to gain approbation. Not everybody has the same learning experiences in life. 
So if the "man within the breast" has not learned to be fully impartial, the admiration that wealth generates may became seductive to the point of overcoming the pleasure derived from moral actions and shadowing the consequences of reprehensible behavior (TMS I.iii.3.8, p. 64-5). When this happens, the adulation of the external spectators prevails over the judgment of the inner spectator, and the moral restraint is weakened. Some will be more easily lured by this external adulation than others. Criminal behavior arises in those who wish to show their own wealth to the point of obtaining it by going beyond the bounds of justice (TMS III.iii.31, p. 149-50). We may read the envy that leads the poor to steal from the rich (WN V.i.b.2, pp. 709-10 and LJB I.13, p. 402) as a subset of this general case, as we discuss later in the paper.

So Smith thinks that the two ways of achieving approbation are not always compatible (TMS I.iii.3.2, p. 62). The best possible scenario is when the two circumstances are both present and people acquire riches and a respectable social status by hard work and fair and virtuous behavior. This is a slow and gradual process, though. It is also the most common.

Given that wealth is much easier to recognize than virtue, for some there is the irresistible temptation to increase wealth at the expense of virtue, especially since we tend to forgive and forget the questionable actions of the rich, given how much we look up to them. Alexander the Great is an example that Smith uses to make the case (TMS VI.iii.28, p. 250): his greatness was achieved through great crimes. Yet, because of his successes, we tend to overlook those great crimes he committed to achieve his great success. So we call him the Great and admire him. Alexander the Great is an example of the reason why, for Smith, we may commit crimes: our desire to gain great approbation from others.

For Smith, this also applies to the great merchants and manufacturers of the Wealth of Nations ([1776] 1981), who are willing to "extort from the legislature [...] laws [...] written in blood" (WN IV.viii.17, p. 648), not only because they criminalize behaviors that would otherwise be natural, such as trade that now becomes smuggling (e.g. WN V.ii.b.6, p. 826-7 and WN 
V.ii.k.64, p. 898), but especially because they are willing and able to found and defend "a great empire" using the "treasure and blood" of their fellow-countrymen to enrich themselves at the expense of the great body of society (WN IV.vii.c.63, p. 613; see also Paganelli 2008; Paganelli 2009). From the early stages of colonization, "folly and injustice" (WN IV.vii.b.59, p. 588) drive the race for wealth of the colonizers, to the "servants" of Joint Stock Companies, of the East India Company in particular, who are "perfectly indifferent" to the disaster they leave the colonies in when they "pervert administration of justice" of the colonies so that they can take with them immense riches (WN IV.vii.c.105-106, p. 638-40): our desire to show off wealth blinds us so much that we commit even the most atrocious crimes.

In a smaller scale, this happens even when a poor person wishes to become more visible and adopts a "loose system of morality" more typical of the wealthy, rather than maintaining the "austere system of morality" more appropriate for his poor condition. His desire to show off, to appear what he is not, will lead the poor man into dissipation and crime (WN V.i.g.10, p. 794). Note that, for Smith, obscurity itself is not enough to incentivize the poor to commit crimes. Indeed when a man of low condition sinks in the obscurity of a large city, he may abandon himself to "profligacy and vice" but not necessarily to crimes (WN V.i.g.12, p. 795). Similarly, need alone is not enough of a motivation for crime in Smith's account. "Want" needs to be accomplished by the "indignation of the poor" against the rich and that needs to be "prompted by envy" (WN V.i.b.2, p. 710).

Thus, for Smith, it is the prospect of gaining great wealth, enough to change our status in the eyes of others, that may motivate some to commit crimes. Smith also explains that the greatness of Alexander, as well as of the first colonizers and of merchants and manufacturers, of their great crimes and successes, comes from their great self-delusion. Our natural self-delusion is indeed an aspect of our natural self-love (e.g. Schliesser 2006; Hanley 2009; Fleischacker 2011), which systematically biases and distorts our perception of reality, and which, Smith explains, may lead some to crime. 
Our self-love naturally biases us so that we do not perceive probability correctly. We may understand that the probability of failure in some specific activity is very high, but we are convinced we are exempt from it. We love ourselves too much to admit failure, or its probability. That probability applies to others, not to us. For Smith, our natural over-confidence, which every person in relative good health has, is what explains the profitability of lotteries and the lack of profitability of insurance (WN I.x.b.26-28, pp. 124-26). The expected value of a lottery is less that its cost, yet many play because they are biased by their "presumptuous hope of success." Of course, they will lose. Mirroring this, the expected value of insuring a ship at sea is higher than its cost, but few merchants insure their ships, according to Smith, because they overestimate their probability of success and underestimate their probability of failure.

The same presumptuous hope of success is also present in the choice of professions, including joining the army in the hope of vain glory (WN I.x.b.30-32, pp. 126-27). The dangers are underestimated and the probability of glory overestimated so much so that young boys join the army against the will of their fathers in great numbers, and as an unintended consequence drive down the salary of soldiers. That presumptuous hope of success also applies to criminal professions, such as smuggling. Smuggling is the most profitable profession, when successful. But the chances of success are very low. High profits attract more and more people, who in their turn, lower the probability of success, increasing the profits of the successful ones (WN I.x.b.33, pp. 127-28).

Smith seems to imply that our self-delusion affects the perception of the size of what we may gain, further biasing our "calculation". The "absurd confidence" that no "judgment of sober reason and experience" would support, led to the baseless belief that in the new lands of the Americas one could find Eldorado (WN IV.vii.b.18-20, p. 562-4). Alexander's delusion of his own grandeur, his estimation of his probability of success of how much he could gain, was so distorted that it resembled "folly". Yet, he succeeded and became the Great. No rational calculation would have ever allowed someone to do what Alexander the Great's "folly" did (TMS VI.iii.28, p. 250). 
So, the other side of the coin of the motivation for crimes, for Smith, is our self-delusion, our systematic bias in perceiving probability of success and failure. This is as close as it gets to a rational calculation in Smith's analysis. It is not much, given the role self-delusion plays. A potential smuggler evaluates his expected benefits and expected costs and acts according to his calculation. But passions prevent this calculation from being "rational" since our self-love systematically biases our perception of the probabilities. Due to self-delusion, there are more smugglers than is "optimal", to use today's terminology, and most of them fail.

There are a couple of additional things to note here. First, even if one wishes to interpret Smith's analysis as a somewhat "rational calculation of costs and benefits" one should not ignore that for Smith, this attitude, which induces a person to earn more and more riches and accumulate properties, is not meant as a hedonistic form of satisfaction typical of utilitarianism, since it aims at a different range of pleasures. A person wishes to have at their disposal a great amount of wealth not simply to enjoy a high degree of utility according to some rational scheme of consumption: the stomach of a rich man is about the same as the stomach of a poor man. But we want more and more riches because, by showing them off, we can be the object of the attention and admiration of our fellows (e.g. WN I.xi.c.31, p. 190; TMS VI.i.3, p. 212-13).

Second, and this may be one of the greatest limitations, if not the greatest one, of Smith's model: Smith can explain only crimes done to achieve gains great enough to change our social status. He does not explain small crimes, or petty crimes where the criminal gains only a small amount. He simply claims we disapprove of those petty crimes and look down on the person who committed them (TMS VI.i.16, p. 217). One may infer that petty crimes may be a miniature version of large crimes, where our delusions induce us to think that the disapprobation we will receive is less than it is. But Smith himself does not describe this in any detail.

Even with this limitation, not only is Smith far from the Legal Enlightenment's understanding of rational crimes - our sentiments always "interfere" by systematically biasing our 
calculations - but his understanding of what makes something a crime is also far from that of the Legal Enlightenment: it is based on our vanity, the systematic biases of our self-love, and the presence of an impartial spectator, even if that spectator is not perfectly impartial. We all share these characteristics, but since nurture is what differentiates a street porter from a philosopher (WN I.ii.4, p. 28-29), the magnitude of these passions will vary across individuals, allowing for virtuous people as well criminals, depending on how much the "man within" has learned to be impartial in a person's life.

Unlike the utilitarian authors, Smith does not believe that a utilitarian calculation can deduce the laws of justice nor that a valuation which correctly foresees benefits and losses can determine the morality of an action. Knud Haakonssen (1981: 183) saw this anti-utilitarianism in Smithian jurisprudence; and Witzum and Young (2013) are even willing to see utility and justice as substitutes in Smith. Indeed, Smith assigns the task of approving human actions to the spontaneous sentiments and judgment of the impartial spectator, as described in Part I of TMS. For Smith it is the spontaneous feeling of the impartial spectator's reaction that identifies what is illicit. This thesis marks an even further distance between Smith and the Legal Enlightenment for which the formulation of general rules of conduct is an ex ante analysis of the allegedly final effects of human actions. Indeed, scholars within the Legal Enlightenment tradition, such as Beccaria, conceive crime as the activity for which the gains an individual receives are less than the losses this individual imposes on another or on society (Beccaria [1764] 1986: VIII, XXVII): crime is a rational social cost-benefit analysis (Simon 2009: 16-17).

Given his distance from Legal Enlightenment cost-benefit analysis, Smith can avoid a problem the Legal Enlightenment cannot: with a cost-benefit analysis, there may be immoral actions which remain unpunished because they produce more benefits for the criminal than costs for the victim. Working with the approbation of the impartial spectator means that Smith avoids this problem. For him, individuals must never prefer themselves to any other individual, as to hurt or injure someone, in order to benefit themselves, even if their benefit should be much greater than the 
other's costs. The poor man must neither defraud nor steal from the rich, even if they might benefit much more than the rich man's loss (TMS III.iii.6, p. 138). ${ }^{2}$

An additional difference between Smith and Legal Enlightenment thinkers is how to direct behavior to improve one's condition and society's condition. For the exponents of Legal Enlightenment, rational legislation and the constitutional framework are valid instruments to direct individual interest towards those activities and conduct that better both one's condition and public wealth (Simon 2009; Simon 2011). But a rational legislation or constitutional framework work only when we assume that the actions of an individual are mainly logical and foreseeable, when we assume that the individual is a rational agent very close to the neoclassical version of homo economicus. Instead, Smith's agent is the opposite: he is not guided by utility maximization but by sentiments that are not necessarily rational. So Smith, rather than being confident in the rationality of an omniscient legislator (Haakonssen 1981: 85-86; Griswold 1999:250-252; Simon 2017), entrusts the task of safeguarding wealth, happiness, and the respectability of the individual from the risk of immoral actions, to the innate virtue of prudence and propriety, directed by the impartial spectator which moderates human passions (TMS, VI.i.6, p. 213. See also Carrasco 2008). His logic, as we will see below, parallels the one he uses to explain the growth of an economy, rooting it in the passions of individual persons, not in a public spirited social rational plan.

\section{Why Punishment?}

If the desire to gain the approbation of the spectators around us is a motivation to commit crimes, the judgment of the spectator inside us is the motivation for punishing these crimes.

\footnotetext{
${ }^{2}$ Smith, in contrast with Grotius, following his own anti-utilitarianism and retributivism, refuses any mitigating circumstance for crimes committed out of extreme poverty (Salter 1999).
} 
For Smith, we judge the propriety of an action as well as its merits or demerits (TMS, II). The propriety of an action concerns the causes of the action. The merit of an action concerns its effects (TMS II.i.5.3, p. 74-5).

When we see someone doing something to someone else, we may feel either gratitude or resentment, meaning we believe that that behavior deserves either reward or punishment. Our judgment usually takes into consideration both the propriety and the merit of the action, that is, both the actor's motivation (propriety) and the consequence on the other person (merit) (TMS II.i.5.5, p. 75. See also TMS, II.i.2.5, p. 70-1). Our judgment of merit completes and strengthens our judgment of propriety of the action. It generates in us a desire to behave in a way that deserves moral reward and avoids resentment. So when we identify with the resentment of the victim more than with the propriety of the action, we think that punishment is appropriate (TMS II.i.4.4, p. 74). Our judgment is generally not the arbitrary result of a partisan individual, since we are far enough from and uninvolved with, the action we observe. Our judgment is formed impartially, and may receive confirmation from a similar judgment by others, strengthening its validity even more (Carrasco 2008).

Consequently, for Smith, punishment is the result of a spontaneous reaction of our feeling of resentment. It is one of the most significant distinguishing elements of Smithian legal theory since it breaks with the mainstream of Legal Enlightenment which, on the contrary, founds punishment on the rational utilitarian calculation of pleasures and pains. A consequentialist theory becomes incompatible with a theory based in the judgment of worthiness of individuals in terms of assessment of the motivations and propriety of the actor (C. Smith 2018). Smith is also able to offer a more coherent justification for punishment than philosophers, such as Immanuel Kant, who try to use a general principle instead (Fleischacker 1988). Consistent with his view of the natural emergence and evolution of institutions, Smith believes that Nature has entrusted the formulation of rules of conduct not to a rationalistic logic and a methodical speculation, but rather to instincts and passions (TMS II.i.5.10, p. 77-8). 
So, punishment is not a price that a rational legislator conceives to curb unwelcomed social actions but a natural reaction determined by a feeling of revenge, a natural offspring of resentment (TMS II.i.2.5, pp. 70-1; TMS II.ii.1.5, pp. 79-80). In contrast with other scholars of his age, Smith doesn't banish vengeance from the penal system (Fleischacker 1988). On the contrary, he endorses the appeasing of the victim's resentment through the pain of the guilty. The Smithian idea of punishment, therefore, far from the new reformist trend of the 18th century, remains an expiation theory which can be summarized with the sequence: resentment-expiation-gratification. ${ }^{3}$ For Smith, though, this expiation is not a religious one nor does it aim to restore the authority of the sovereign through the torment of criminal's body (cf. Foucault 1975: 8-72). These latter expiations would be the base of the "laws of police" rather than the "laws of justice," a distinction that John Millar attributes to Smith himself (Cairns 1988, 394).

Smith's contrast with an author such as Cesare Beccaria is stark. Beccaria refuses to use legal sanctions as an instrument to satisfy the victim as they would be useless: "Can the cries of a poor wretch turn back time and undo actions which have already been done?” (Beccaria [1764] 1986: XII). Revenge is not restorative, thus useless. For Smith, instead, justice is retributive, in the sense that it aims at the punishment of the criminal, "without reference to any other goods that might arise" (Walen 2016). ${ }^{4}$ Our feelings of resentment, and desire for revenge against the source of

\footnotetext{
${ }^{3}$ Alain Norrie (1989, pp. 230-34) distinguishes the idea of "retributivism", which aims to amend the criminal, from one of "retribution" whose purpose is the mere gratification of victim's resentment and that appears the real criterion selected by Smith. Less convincing is Norrie's attempt to find elements of utilitarianism in Smith's use of both concepts.
}

4 A standard definition of retributive justice is "The concept of retributive justice has been used in a variety of ways, but it is best understood as that form of justice committed to the following three principles: (1) that those who commit certain kinds of wrongful acts, paradigmatically serious crimes, morally deserve to suffer a proportionate punishment; (2) that it is intrinsically morally 
our suffering, are so strong, so natural (and so irrational), that all animated beings feel them even against an inanimate object that hurts them: "We are angry, for a moment, at the stone the hurts us. A child beats it, a dog barks at it, a choleric man is apt to curse it" (TMS II.iii.1.1, p.94). Smith insists: "the object that caused [great harm] becomes so disagreeable to us even after, and we take pleasure to burn or destroy it. We should treat, in this manner, the instrument which had accidentally been the cause of the death of a friend, and we should often think ourselves guilty of a sort of inhumanity, if we neglected to vent this absurd sort of vengeance upon it" (TMS II.iii.1.1, p. 94). The feeling of gratitude for inanimate objects that accidentally help us mirrors it (TMS II.iii.1.2, p. 94).

The piacular feeling of remorse or regret for the harm we unintentionally cause to someone else is also an expression of the "absurd" strength of our feelings: we do not question the propriety of our action, so we are not properly guilty of the accidental harm we caused, and yet we desire to apologize or atone. Keith Hankins (2016) goes so far to explain these irregular feelings as necessary to support and strengthen our moral responsibility, given the pervasive presence of luck in our lives (see also Williams 1976; Schliesser 2013; Schliesser 2017, p. 121-136). Eric Schliesser (2017) goes farther and sees the piacular as a "species of shame" which may lead to permanent "stain" and "real danger to the mental health of well-formed minds" (129) so much so that atonement for accidentally hurting others may include taking one's own life.

The focus is thus strictly on the victim, not the criminal. Criminals do not need to understand their punishment. Punishment is not deterrence: it is just the way to satisfy the natural desire of seeing what the victim feels the morally deserved suffering in the wrongdoer.

good — good without reference to any other goods that might arise — if some legitimate punisher gives them the punishment they deserve; and (3) that it is morally impermissible intentionally to punish the innocent or to inflict disproportionately large punishments on wrongdoers." Walen 2016 
But the victim's desire for revenge risks excesses and disproportional reactions. Revenge risks becoming cruelty. For Smith the judge of the appropriate measure of punishment is, again, the impartial spectator. The sympathy of the spectator is the judge not only of the behavior deserving resentment but also of the measure within which this resentment can be exercised and contained (TMS I.i.5.4, p. 24; LJA ii.90, p. 104). The impartial spectator constrains the victim's wish for vengeance into a fair retributive punishment, as the impartial spectator will not approve of disproportionate reactions. In addition, as shown below, the public magistrate will also play a role in institutionalizing revenge into its proper constraints.

Furthermore, as Richard Stalley (2012: 75-76) and Christel Fricke ([2011] 2017: 234-235) well recognize (see also Fleischacker 2005, C. Smith 2013, Schwarze and Scott 2015), for Smith not all behaviors deserving moral reproof deserve punishment. Hurting someone is what makes the difference between deserving and not deserving punishment (TMS II.ii.1.5, p. 79-80; TMS, II.iii.3.2, pp. 105-06). This is possibly one of the most important parts of the Smithian theory because it explains the origin of justice and its unintentional role in the survival of society (for a debate on whether distributive justice is part of this idea of justice see Fleischacker 2005 and C. Smith 2013).

For Smith, acts of charity and of disinterested benevolence deserve approval and reward; but their omission, or the lack of gratitude as a consequence of them, do not cause an intolerable unhappiness to people, do not expose them to any risk, and so do not provoke indignation and hatred in the spectator (TMS II.ii.3.3-4, p. 86). Punishment cannot be called for when charity or benevolence are missing. Indeed the very idea of using punishment to induce beneficence would undermine the concept of beneficence. Benevolence and beneficence cannot be extracted by force (see C. Smith 2013, see also V. L. Smith and Wilson 2019). Whereas hurting someone raises our resentment and requires a strong response. This response satisfies the sense of justice, while, unintentionally, also defending individuals from other similar harmful acts. Therefore, as the impartial spectator dictates, the only tasks of justice are redress and defense (TMS, II.ii.1.4, p. 79). 
The Smithian idea of injury in some aspects appears to coincide with the Legal Enlightenment's view of damage. Both break with the Ancien Regime tradition which identified sin and crime; both define the seriousness of the criminal action and the corresponding punishment. Yet, beyond the appearances there is a deep difference between the two theories. The damage described in the works of utilitarian scholars is the tangible result of an economic calculation of the loss and gain of socially undesirable behaviors and the same for the punishment which should discourage them. Instead, Smith's injury is more about the sentiments of someone, harmed in his body, property, or freedom, who feels above all that his dignity is injured. A subjective and personal resentment which the approbation of the impartial spectator transforms in a positive and objective datum.

Smith does not offer a clear distinction between injuries deserving private punishment and injuries that deserve an institutionalized punishment, most likely because the line will depend on the peculiarity of societal circumstances. As we see below, different societies have different legal structures depending of what is appropriate to their circumstances. Similarly the demarcation between a general wrongdoing and a crime may be left to the peculiar circumstances of each society. In Smith, the distinction between a legal crime and a behavior that deserves punishment is not well defined, even if the two do not necessarily overlap, as we will see below.

Smith therefore consistently applies his understanding of human nature, which sees human beings as creatures with sentiments rather than simply utility calculators, in both his theory of crime and his theory of punishment. Grounded in individual feelings, Smith's theory of crime and punishment generates a theory of criminal justice based on the individual person, and not meant to promote what is good for society, even if it does achieve this unintentionally. Smith's criminal legal theory fits comfortably within the same system with which he describes the economic system, as well as within the Scottish Enlightenment idea that well-functioning social institutions are the result of human action but not of human design, but it greatly diverges from the views of the Legal Enlightenment. 


\section{Why public magistrates?}

Engaging in the study of the science of man implies distinguishing between the permanent and the contingent. Smith sees that our desire to achieve the approbation of others, through virtue and wealth, and our systematic overestimation of our probability of success and underestimation of our probability of failure, are permanent features of our being. The presence of "the man within the breast" judging the propriety and the merits of our actions is also part of our unchangeable nature. What is contingent is the material and institutional context in which we live, including the level of wealth and the opportunities to gain great wealth, and thus the strength of the incentives to commit crimes.

In pre-commercial societies, the desire to parade wealth is just as strong as in commercial societies, but there is less wealth to parade, so, everything else the same, we observe little showing off of wealth. In a society of hunters, approbation comes mostly from physical achievements or wisdom, since wealth is highly perishable, private property is thus practically non-existent, and significant accumulation of wealth is unlikely. With no property, the only possible injuries are either physical or reputational. These injuries do not benefit the injurer though, so they are not very frequent, according to Smith. Prudence and the impartial spectator work relatively well, given the weakness of the incentives. There is no need for a civil authority and indeed there is none (LJB I. 19-20, pp. 404-05; WN V.i.b. 2, p. 709).

But as wealth becomes less perishable and can be accumulated, private property is more likely to be present, and wealth becomes an easier and less controversial way to achieve the approbation of others. This also means that there is more wealth to seduce and weaken moral restraints. And given property, the injurer does benefit from injuring his victim. "Avarice and ambition in the rich... [and their] affluence...excites the indignation of the poor, who are often both driven by want, and prompted by envy, to invade his possessions": crimes become more likely (WN V.i.b.2, p. 709) and the presence of a civil magistrate becomes necessary to guarantee security. "It is 
only under the shelter of the civil magistrate that the owner of that valuable property, which is acquired by the labour of many years, or perhaps of many successive generations, can sleep a single night in security (WN V.i.b.2, p. 709): we now see penal laws and judges enforcing them (WN V.i.b.2, p. 710).

For Smith the origin of legal and civil authority therefore is a consequence of the emergence of property and its diffusion (see also LJB I.11, p. 401) based on passions such as avarice, ambition, indignation, envy, and fear. And when the division of labour separates the roles of judge and legislator from that of executive, then we have secure general rules that are freed from political expediency (WN III.ii-iv). The legitimacy of political and juridical institutions are thus a byproduct of the people's approved conduct (Carrasco 2008, p. 151).

So the first condition under which punishment requires institutionalization is the presence of crimes, which we see more often when there are the incentives to commit them and fear of being a victim of one, that is, when there is wealth (WN V.i.b.2, pp. 709-710; LJB I.11-13, pp. 401-402). The second condition is the possibility that punishment escalates into disproportional revenge (TMS I.i.5.4, p. 24; LJA ii.90-100, pp. 104-108). The injurer's spectator is not impartial, by the simple fact that the injurer commits a crime. The victim's internal spectator may also not be impartial, given the closeness of the injury. The unconscious temptation to magnify the hurt out of proportion is very much present. If that is the case, punishment may not be proportional to the crime, and can escalate in a vicious spiral of violence. Legal justice and its public authority emerged as a mechanism that evolved from mediating the fear of being injured, and private vengeance and retaliation which could otherwise escalate into a feud, "prevent[ing] the ill consequences which might arise from those crimes [and] preserving the publick peace" (LJA ii.95, p. 106). 
Deterrence is obtained unintentionally by assuring the satisfaction of the victim's resentment (LJA ii.93, p. 105). ${ }^{5}$ What today we would recognize as efficiency is here again an unintentional result - as usually happens when Smith analyses the origin of institutions. So, the fundamental feature of the Smithian idea of criminal justice is a marked focus on the person which contrasts with the holism typical of the Legal Enlightenment's theory of criminal justice as a social defense.

Smith's legal theory is thus in open conflict with contract theories, as civil authority emerges only under specific circumstances (WN V.i.b.1-12, pp. 708-715, LJB 92-93, pp. 433-434), and not from a deliberate decision (see also LRBL, p. 176). ${ }^{6}$ It also differs from the theory of deterrence of the Legal Enlightenment. In the center-stage of Smith's work there is always the individual person; their interest is the ultimate aim of the authorities' intervention. Justice is to defend each person and their property, not society as a whole. We can see the pivotal role of the individual person when we see that Smith puts the origin of the right to punish in the resentment of the victim and in the gratification of this personal sentiment. The dissuasion from committing further hypothetical crimes is just one of the side effects of the penal rules, but it is not the main motive which turns resentment into a legal sanction ${ }^{7}$ (TMS II.ii.1.4-5, pp. 79-80; LJ). Smith is

${ }^{5}$ According to Stalley (2012, pp. $75-77$ ) the natural desire to gain the approbation of others is a sentiment able to induce the criminal to accept the punishment, admit the guilt and repent. This spontaneous mechanism allows an individualist punishment based on the resentment to procure a social vantage such as the correction of criminals and the deterrence of further crimes. Yet Stalley focuses on the approbation process only to explain how punishment works without any reference to the reasons which motivate a crime.

${ }^{6}$ Regarding Smith's general legal theory see also Haakonssen 1981; Malloy and Evensky 1994; Malloy 2012; Lieberman 2006; Malloy 2017.

7 Even if Smith establishes a cardinal ordering of the punishment founded on the resentment analysis (Lindgreen 1994: 66), unlike the authors of the Legal Enlightenment, he does not reach the 
aware of this intellectual distance from the exponents of Legal Enlightenment and underlines it, openly declaring his opposition towards the theorists of "publick good" (LJA ii.91, p. 104). For Smith, these followers of Grotius focus on the "correction of the offender", on "the deterring of others" and on "the safety of the community" (LJA ii.169, p. 136), placing the defense of society first and only indirectly dealing with the individual. Smith explicitly overturns them with his psychology of crime and punishment: he tells that, for example, we want to punish one who stole some change from us, not because we are afraid that the loss of few pennies will compromise our fortune, but because the loss of those few small coins upsets us. Similarly, we want to punish the person who injured another, not because we care about society, but because we care about the injured person (TMS, II.ii.3.10, pp. 89-90).

Furthermore, in contrast to the exponents of Legal Enlightenment who consider punishment as lawful only when it discourages illegal acts, and vengeance as an excessive suffering and thus an excessive cost to society, Smith believes that when we stray from the criterion of resentment to embrace society's security, in the name of public interest, we risk inflicting punishment beyond the measure suggested by the impartial spectator (LJA ii.91, p. 104). ${ }^{8}$ A legislator who adopts this doctrine could punish innocuous behavior and limit personal freedom to maximize public welfare. In addition, punishing to pursue public good may also be ineffective. Positive law may mimic

formulation of a theory of marginal deterrence which is the core of today's economic analysis of crime and punishment.

${ }^{8}$ Smith's dissent from the Legal Enlightenment theory of social defense could be the explanation of the unpublished manuscript fragment which today is in the Appendix of TMS edited by D.D. Raphael and Macfie 1984, p. 390. The risk of "improper punishment" arises when the justice renounces the criterion of resentment and extend its task beyond the protection of natural rights (Simon 2013, p. 406). 
natural justice, but it may also follow utilitarian goals. Since punishment is the consequence of human passions and feelings, if it pursues public targets which are unconnected with natural resentment, individuals' judgments may only feebly share its propriety. This is may be another of Smith's most original contributions: utilitarian punishment may fail. Indeed, Smith is so aware that punishment may fail and our resentment go unsatisfied, that he believes that to calm our tormented sentiments, we lean on divine justice to make up for the lack of appropriate human justice (TMS II.ii.3.12: 91. See also C. Smith 2018 and Schwarze and Scott 2015).

It may not be by accident that, if with a utilitarian criterion we punish some offenses in a way that is deemed too light to satisfy the victim's resentment, duels emerge as a way of appeasement and to recover honor (LJA ii.137, p. 123). Similarly, in a more controversial passage of TMS (II.ii.3.11, pp. 90-1), Smith allegedly claims that we justly punish with death a sentinel who falls asleep potentially jeopardizing the whole army, so that others may be deter from falling asleep. His language is tentative, though, reflecting the hesitation of the impartial spectator and how reluctantly he makes himself agree that the severity of the punishment is appropriate given the absence of resentment. Smith goes so far to claim that even "A man of humanity must recollect himself, must make an effort, and exert his whole firmness and resolution, before he can bring himself either to inflict it, or to go along with it when it is inflicted by others" (TMS, II.ii.3.11, p. 90. See also LJA ii.90-2, pp. 104-05). That the individual is sacrificed for the alleged wellbeing of society and this decision is not necessarily approvable (see also Schwarze and Scott 2015; C. Smith 2018; C. Smith 2019). Raphael (1972-3, p. 95-96) indicates this reluctance to punish the sleepy sentinel as the exception that proves the rule: a punishment perceived as excessive compared to the resentment it generates is extremely difficult to accept and perform exactly because we approve only of punishment proportioned to the crime. Witzum and Young (2013, p. 584) push Raphael's argument further claiming that judging of it as just is an ex-post consideration of the philosopher.

While the sentinel will be executed, even if extremely reluctantly, other crimes meant to protect the whole society may not be punished, if the positive law does not reflect natural justice. 
When Britain punished with death the exportation of wool claiming that exporting wool would injure the whole society, it became almost impossible to find jurors or witnesses against the smugglers. People refused to inflict punishment for something they did not see meeting the conditions for resentment (LJA ii.90-2, pp. 104-05; WN IV.viii.19, p. 648-49). In this circumstance people show scarce cooperation with the legal justice, jeopardizing its enforcement. Smith's logic here is remarkably similar to the one used to justify abandoning attempts to draft and enforce economic policies meant to promote the public good: they generally are either superfluous or counterproductive (WN IV.ii.11, p. 456).

\section{Conclusion}

Smith believes that resentment is the original source of the right to punish, that it has to be the main object of criminal justice, and that it is also the proper measure of a fair punishment. He does not believe crime is the result of a rational calculation. Rather Smith sees crime as caused by envy and the immoderate desire of acquiring riches to parade, through any means, combined with our systematic presumptuous hope of success. So, a utilitarian punishment -based on a hedonistic calculation of pleasure and pain and on a reliable forecast of the probability of enforcement- could not effectively deter a criminal. Attempts to rationally redesign the criminal justice system based on premises that do not correspond to human sentiments, such as utilitarian criteria, would thus reform the system for the worst.

The theory of criminal justice described in LJ and $\mathrm{WN}$ is consistent with the ethical premises of TMS: ${ }^{9}$ both are founded on the judgment of the impartial spectator whose imaginary and metaphorical role in the civil society is played by the magistrate. We thus concur with John Cairns (1994, p. 54) who argues that for Smith common law is found on moral sentiments, as in

\footnotetext{
${ }^{9} \mathrm{In} \mathrm{LJ}$ there is an explicit reference to Smith's lectures on moral theory which deal with the topic (LJA i.36, p. 17).
} 
judge-made law systems the magistrate plays the role of the impartial spectator. This institutional actor judges by taking into consideration the injury that the crime caused, the consequent resentment of the victim, and the society which sympathizes with him.

Attempts to bring justice to the individual victim unintendedly create a well-functioning legal system, whereas attempts to rationally redesign this system, like some Legal Enlightenment projects would propose, would switch the attention from individual justice to social public good. They would ignore human nature and the changing circumstances of the reality of human praxis and local knowledge (Carrasco 2008; C. Smith 2013) and thus risk creating more damage than the damage they intend to mend, by having to force individuals to move, like pieces on a chessboard, in the directions they would not want to move to.

The man of system ... seems to imagine that he can arrange the different members of a great society with as much ease as the hand arranges the different pieces upon a chessboard. He does not consider ... [that] every single piece has a principle of motion of its own altogether different from that which the legislature might chuse to impress upon it. If those two principles coincide and act in the same direction, the game of human society will go on easily and harmoniously, and is very likely happy and successful. If they are opposite or different, the game will go on miserably, and the society must be at all times in the highest degree of disorder (TMS VI.ii.2.17, pp. 233-4).

This does not necessarily imply, as Paul Russell (1995, pp. 137-153) argues, that Smith's retributivist penal system, unlike Hume's one, precludes any hypothesis of legal reform and legal progress. Stalley (2012, pp. 82-85), replying to Russell, suggested instead that for Smith human beings are naturally inclined towards change so that the evolution of their sentiments also determines the evolution of legal systems. 
Our position is instead that Smith rejects great rationalist reforms, such as a "man of system" would design, and yet he hopes the wisdom of the "legislator" would introduce single and specific reforms required by historical circumstances. This conclusion is also shared by Donald Winch (1998, p. 372)-who distinguishes Bentham's reformism from Smith's (see also Haakonssen 1981, pp. 135-153; Cairns 1994, pp. 32-33; Samuels and Medema 2005). This reading is also consistent with Haakonssen (1981) and Cairns (1994) who argue that Smith prefers to entrust the reform of the legal system to judges rather than the legislator. Craig Smith (2013), though, believes that the legislator can still play a positive role, when distinguished from the politician: "The legislator deals with rules guided by general principles; 'that insidious and crafty animal, vulgarly called a statesman or politician' (WN IV.ii.39, p. 468) deals in compromise and expediency" (p. 792).

Smith's criminal theory, when considered in all its aspects-from the motivations to commit crimes, to the justification of punishment, to the emergence of a civil magistrate - is remarkably consistent with his economic theory. Neither emerge from an intentional rational plan aimed at achieving some social good. Both rely on actions meant to satisfy individual's passions instead. In both cases the social good, or efficiency, are the results of human actions but not of human design. The "man of system" may be equally dangerous for both reforming the economy and the law. Understanding human nature with all its passions and sentiments, trusting the individual persons despite all their biases and limitations, generally unintentionally generates better functioning institutions than the ones rationally designed while ignoring the passionate aspects of human nature. For Smith, this is true of the economic system. And it is true also for the criminal legal system. 


\section{Acknowledgments}

We thank three anonymous referees and the editor of this journal for constructive comments, as well as Tyler Cowen, Eric Schilesser, Craig Smith, Vernon Smith, Bart Wilson, the participants of the 2019 History of Economics Society meeting, of the 2019 European History of Economic Society meeting, of the 2019 International Adam Smith Society meeting, of the 2019 Creighton University Humanomics colloquium, and of the 2018 New York University colloquium. All mistakes are ours.

\section{Bibliography}

Bayne, Alexander. [1730] 2010. Institutions of the Criminal Law of Scotland. Gale Ecco, Print Editions

Beccaria, Cesare Bonesana di. [1764] 1986. on Crimes and Punishments, Ed. and Transl. by D. Young from Dei Delitti E Delle Pene,. Indianapolis: Hackett Publishing Company.

Becker, Gary S. 1968. "Crime and Punishment: An Economic Approach." The Journal of Political Economy. 76: 169-217.

Bentham, Jeremy. [1780] 1948. 'An Introduction to the principles of Morals and Legislation' in W. Harrison (ed.) A Fragment of Government and An Introduction to the principles of Morals and Legislation, 113-435. Oxford: Basil Blackwell.

Campbell, Tom. 2013. "Adam Smith: Methods, Morals, and Markets" In The Oxford Handbook of Adam Smith, edited by Christopher J. Berry, Maria Pia Paganelli and Craig Smith, 559-580. Oxford: Oxford University Press.

Cairns, John W. 1994. "Adam Smith and the Role of the Courts in Securing Justice." In Adam Smith and the Philosophy of Law and Economics, edited by Robin Paul Malloy and Jerry Evensky, 31-61. Dordrecht: Kluwer Academic Publishers.

. 1988. "John Millar's Lectures on Scots Criminal Law." Oxford Journal of Legal studies. 8.3:364-400.

Carrasco, Maria A. 2008. "Adam Smith on Morality, Justice and The Political Constitution of Liberty." The Journal of Scottish Philosophy 6(2): 135-156.

Cremaschi, Sergio. 1989. "Adam Smith. Sceptical Newtonianism, Disenchanted Republicanism, and the Birth of Social Science." In Knowledge and Politics: Case Studies on the Relationship between Epistemology and Political Philosophy, edited by M. Dascal and O. Gruengard, 83110. Boulder, Co: Westview Press. 
Erskine, John. [1754] 2018. The Principles of the Law of Scotland: In the Order of Sir George Mackenzie's. Institutions of that Law. 2 vols. Gale Ecco, Print Editions.

Filangieri, Gaetano. [1780-91] 1984. La Scienza Della Legislazione. Roma: Istituto Poligrafico e Zecca dello Stato.

Fiori, Stefano. 2012. "Adam Smith on Method: Newtonianism, History, Institutions, and the "Invisible Hand"." Journal of the History of Economic Thought 34 (3): 411-435.

Fleischacker, Samuel. 2011. "True to Ourselves? - Adam Smith on Self-Deceit." Adam Smith Review 6: 75-92. .2005. On Adam Smith's Wealth of Nations: A Philosophical Companion. Princeton: Princeton University Press. . 1988. "Kant's Theory of Punishment" Kant-Studien (79, 1-4): 434-449.

Forbes, William. [1730] 2013. The Institutes of the Law of Scotland. Volume Second. Comprehending the Criminal Law. In Two Parts. RareBooksClub.com

Foucault, Michel. 1975. Surveiller Et Punir. Paris: Gallimard.

Fricke, Christel. [2011] 2017. "Adam Smith and 'The most Sacred Rules of Justice'." In Adam Smith and Law, edited by Robin Paul Malloy, 225-253. Oxen: Routledge.

Griswold, Charles. 1999. Adam Smith and the Virtues of Enlightenment. Cambridge: Cambridge University Press.

Grossi, Paolo. 2010. A History of European Law. Malden-Oxford: Wiley-Blackwell.

Haakonssen, Knud. 1981. The Science of a Legislator. the Natural Jurisprudence of David Hume and Adam Smith. Cambridge: Cambridge University Press.

Hankins, Keith. 2016. "Adam Smith's Intriguing Solution to the Problem of Moral Luck." Ethics (126): 711-746.

Hanley, Ryan Patrick. 2009. Adam Smith and the Character of Virtue New York : Cambridge University Press, 2009.

Hetherington, Norriss S. 1983. "Isaac Newton's Influence on Adam Smith's Natural Laws in Economics." Journal of the History of Ideas 44 (3): 497-505.

Hollander Samuel. 2016."Ethical Utilitarianism and the Theory of Moral Sentiments: Adam Smith in Relation to Hume and Bentham." Eastern Economic Journal 42 (4): 557-580.

Home, Henry, Lord Kames. [1758] 2019. Historical Law- Tracts. Indianapolis: Liberty Fund.

Hume, David. [1939] 1976. A Treatise of Human Nature. edited by L.A. Selby-Bigge, rev. P.H. Nidditch. Oxford: Clarendon.

Knight, Frank H. 1944. "The Rights of Man and Natural Law" Ethics, 54 (2): 124-145 
Levy, David M. 1995. "A Partial Spectator in the Wealth of Nations: A Robust Utilitarianism." European Journal of the History of Economic Thought 2: 299-326.

Lieberman, David. 2006. "Adam Smith on Justice, Rights and Law." In The Cambridge Companion to Adam Smith, edited by Knud Haakonssen, 214-245. Cambridge: Cambridge University Press.

Lindgreen, J. Ralph. 1994. "Adam Smith's Treatment of Criminal Law." In Adam Smith and the Philosophy of Law and Economics, edited by Robin Paul Malloy and Jerry Evensky, 63-81. Dordrecht: Kluwer Academic Publishers.

MacCormick, Neil. 1981. "Adam Smith on Law." Valparaiso University Law Review 15: 243-263.

Mackenzie, Geroge. [1722] 2010. The Works of that Eminent and Learned Lawyer, Sir George Mackenzie of Rosehaugh, Advocate to King Charles II and James VII, 2 vols. Gale Ecco, Print Editions.

Malloy, Robin Paul. 2017. Adam Smith and Law. Oxen: Routledge.

2012. "Adam Smith Nelle Corti Degli Stati Uniti. (Adam Smith in the Courts of the United States. with English Summary.)." Mercato Concorrenza Regole 14 (3): 463-482.

Malloy, Robin Paul and Jerry Evensky, eds. 1994. Adam Smith and the Philosophy of Law and Economics. Dordrecht: Kluwer Academic Publishers.

Millar, John. [1779] 2006. The origin of the distinction of ranks, or, An inquiry into the circumstances which give rise to influence and authority, in the different members of society / John Millar; edited and with an introduction by Aaron Garrett. Indianapolis: Liberty Fund.

Marcos, Maximiliano H. 2009. "Conceptual Aspects of Legal Enlightenment in Europe", in Treatise of Legal Philosophy and General Jurisprudence, vol. 10, edited by Damiano Canale, Paolo Grossi, Hasso Hofmann, Patrick Riley, 69-134. Dordrecht: Springer.

Miller, Eric J. 1996. "Sympathetic Exchange, Adam Smith, and Punishment." Ratio Juris 3: 227-39.

Mizuta, Hiroshi. 2000. Adam Smith's Library: A Catalogue. New York and Oxford: Oxford University Press.

Montes, Leonidas. 2013. "Newtonianism and Adam Smith." In The Oxford Handbook of Adam Smith, edited by Christopher J. Berry, Maria Pia Paganelli and Craig Smith, 36-5-3. Oxford: Oxford University Press.

Montesquieu, Charles de Secondat. [1748] 1989. The Spirit of the Laws. Cambridge New York: Cambridge University Press.

Norrie, Alan. 1989. "Punishment and Justice in Adam Smith." Ratio Juris 2 (3): 227-239.

Padoa Schioppa, Antonio. 2017. A History of Law in Europe: From the Early Middle Ages to the Twentieth Century. Cambridge: Cambridge University Press. 
Paganelli, Maria Pia. 2008. "The Adam Smith Problem in Reverse: Self-Interest in "The Wealth of Nations" and "The Theory of Moral Sentiments"." History of Political Economy 40 (2): 365382.

2009. "Approbation and the Desire to Better One's Condition in Adam Smith : When the Desire to Better One's Condition does Not Better One's Condition and Society's Condition . ." Journal of the History of Economic Thought 31 (1): 79-92.

2017. "We are Not the Center of the Universe: The Role of Astronomy in the Moral Defense of Commerce in Adam Smith." History of Political Economy. (31): 79-92.

Phillipson, Nicholas T. 2010. Adam Smith: An Enlightened Life. New Haven and London: Yale University Press.

Posner, Richard. 1973. Economic Analysis of the Law. Boston: Brown and Company.

Raphael, David Daiches. 1972-73. "Hume and Adam Smith on justice and utility." Proceedings of the Aristotelian Society n.s. 73: 87-103.

Raphael, David Daiches and L. A. Macfie. 1984. "Appendix II." In The Theory of Moral Sentiments by Adam Smith. Indianapolis: Liberty Fund.

Redman, Deborah A. 1993. "Adam Smith and Isaac Newton." Scottish Journal of Political Economy (40): 210-230.

Rizzo, Mario. Forthcoming. "The Impartial Spectator and the Strictness of Rules" Adam Smith Review.

Russell, Paul. 1995. Freedom and Moral Sentiments. Oxford: Oxford University Press.

Salter, John. 1999. "Sympathy with the Poor: Theories of Punishment in Hugo Grotius and Adam Smith." History of Political Thought XX: 205-224.

Samuels, Warren J. and Steven G. Medema. 2005. "Freeing Smith from the "Free Market": On the Misperception of Adam Smith on the Economic Role of Government." History of Political Economy 37 (2): 219-226.

Schliesser, Eric. 2017. Adam Smith: Systematic Philosopher and Public Thinker. New York: Oxford University Press. 214.

2006. "Adam Smith's Theoretical Endorsement of Deception." Adam Smith Review 2: 209-

2013. "The Piacular, Or on Seeing Oneself as a Moral Cause in Adam Smith." In Contemporary Perspective in Early Modern Philosophy, edited by Lenz, Martin, Waldow, Anik, 159-177. Dordrecht, Heidelberg, New York and London: Springer.

Schwarze, Michelle, A., and John Scott, T. 2015. "Spontaneous Disorder in Adam Smith's Theory of Moral Sentiments : Resentment, Injustice, and the Appeal to Providence", The Journal of Politics, 77: 463. 
Simon, Fabrizio. 2017. "Adam Smith and Gaetano Filangieri. Two Alternative Faces of Enlightenment Science of Legislator." Adam Smith Review 10: 41-71.

2013. "Adam Smith and the Law, ." In The Oxford Handbook of Adam Smith, edited by Christopher J. Berry, Maria Pia Paganelli and Craig Smith, 393-416. Oxford: Oxford University Press.

. 2009. "Criminology and Economic Ideas in the Age of Enlightenment." History of Economic Ideas XVII (3): 11-38.

2011. "An Economic Approach to the Study of Law in the Eighteenth Century. Gaetano Filangieri and La Scienza Della Legislazione." Journal of the History of Economic Thought 33: 223-248.

Smith, Adam. [1776] 1981. An Inquiry into the Nature and Causes of the Wealth of Nations. Indianapolis: Liberty Classics.

. [1762-3, 1766] 1982. Lectures on Jurisprudence, edited by Ronald L. Meek, David Daiches Raphael and Peter Stein. The Glasgow Edition of the Works and Correspondence of Adam Smith ed. Indianapolis: Liberty Fund.

. [1759] 1984. The Theory of Moral Sentiments. Indianapolis: Liberty Classics.

1982. Essays on Philosophical Subjects, edited by Ian Simpson Ross. Indianapolis: Liberty Classics.

Smith, Craig. 2019. "Adam Smith on Moral Luck and the Invisible Hand." In The Routledge Handbook of the Philosophy and Psycology of Luck, edited by Ian Church and Robert Hartman: Routledge.

2018. "Adam Smith on Philosophy and Religion." Ruch Filozoficzny 74 (3): 23-39.

. 2013. "Adam Smith: Left or Right?". Political Studies 61: 784-798.

Smith, Vernon L. and Bart J. Wilson. 2019. Humanomics: Moral Sentiments and Wealth of Nations for the Twenty-First Century. New York: Cambridge University Press.

Stalley, Richard. 2012. "Adam Smith and the Theory of Punishment." Journal of Scottish Philosophy 10 (1): 69-89.

Tegos, Spiros. 2013. "The Two Sources of Corruption on Adam Smith." Adam Smith Review 7.

Verri, Pietro. [1776-77] 2010. "Osservazioni Sulla Tortura." In Scritti Politici E Della Maturità. Edizione Nazionale Delle Opere Di Pietro Verri, a Cura Di Carlo Capra. Vol. 6. Roma: Edizioni di Storia e Letteratura.

Vivenza, Gloria. 2008. "Justice for the Criminal. Classical Themes at the Origin of Smithian Ideas." Adam Smith Review 4: 8-25.

Voltaire. [1777] 1999. Prix De La Justice Et De L'Humanité. Paris: L'Arche Editeur. 
Walen, Alec. 2016. "Retributive Justice", in The Stanford Encyclopedia of Philosophy, edited by Edward N. Zalta. Winter 2016 Edition

Williams, Bernard. 1976. "Moral Luck." Proceedings of the Aristotelian Society 50: 115-135.

Winch, Donald. 1998. "Adam Smith and the Liberal Tradition." In Adam Smith, edited by Knud Haakonssen, 359-380. Aldershot: Ashgate-Dartmouth.

Witztum, Amos and Jeffrey T. Young. 2013. "Utilitarianism and the Role of Utility in Adam Smith." The European Journal of the History of Economic Thought 20 (4): 572-602. 